Regulation and Differences in Financial Institutions

Author(s): Victoria Chick and Sheila C. Dow

Source: Journal of Economic Issues, Vol. 30, No. 2 (Jun., 1996), pp. 517-523

Published by: Association for Evolutionary Economics

Stable URL: http://www.jstor.org/stable/4452250

Accessed: 08/01/2010 09:12

Your use of the JSTOR archive indicates your acceptance of JSTOR's Terms and Conditions of Use, available at http://www.jstor.org/page/info/about/policies/terms.jsp. JSTOR's Terms and Conditions of Use provides, in part, that unless you have obtained prior permission, you may not download an entire issue of a journal or multiple copies of articles, and you may use content in the JSTOR archive only for your personal, non-commercial use.

Please contact the publisher regarding any further use of this work. Publisher contact information may be obtained at http://www.jstor.org/action/showPublisher?publisherCode=aee.

Each copy of any part of a JSTOR transmission must contain the same copyright notice that appears on the screen or printed page of such transmission.

JSTOR is a not-for-profit service that helps scholars, researchers, and students discover, use, and build upon a wide range of content in a trusted digital archive. We use information technology and tools to increase productivity and facilitate new forms of scholarship. For more information about JSTOR, please contact support@ jstor.org.

Association for Evolutionary Economics is collaborating with JSTOR to digitize, preserve and extend access to Journal of Economic Issues. 


\title{
Regulation and Differences in Financial Institutions
}

\author{
Victoria Chick \\ and \\ Sheila C. Dow
}

Some regulation of financial markets is accepted even in these dirigiste times and even by those neoclassical economists who find it a struggle to explain why the market for money is different from the market for peanuts.

Monetary regulation as defined in this paper has three parts: the legal framework, monetary policy, and the supervision of banking and financial markets. Historically, these roles have developed alongside the systems they regulated, new measures being created by the monetary authorities-or even by large private banksas specific problems presented themselves. Within this evolutionary framework, policies were tailored to the institutions as they existed at the time. Thus, when banks provided only a minor proportion of monetary instruments, prudential regulation was left to the banks themselves and caveat depositor. When bank-issued notes began to create what we would now describe as macroeconomic instability, the government/monetary authority took over the issue of notes. When bank credit and deposits became a force to reckon with, the authorities devised such instruments as reserve or liquid asset requirements and, where the development of securities markets allowed it, open market operations to keep the banks on a short lead. Each of these episodes marks a shift in the power to provide money, first away from the state to the private sector, then back again as the state regains control. The current situation, almost everywhere in the developed world, is that the power to create money lies almost entirely with the private sector.

The current situation in the European Union (EU) bears some similarities to the situation at the time of the institution of the Federal Reserve System, which, of

The authors are Professor of Economics, University College London, and Reader in Economics, University of Stirling. This paper was presented at the annual meeting of the Association for Evolutionary Economics, San Francisco, California, January 5-7, 1996. 
course, came on the scene after a common currency was already in place but when communications were slow and there were distinct differences in the regional economies of the United States. These differences were the reason for the federal structure of the Federal Reserve System, with each Federal Reserve Bank having the power to operate interest rate policy according to local needs. The great diversity of state legal frameworks under which banks were chartered and regulated, and the diversity of banks in terms of their size, their branching, and their local situation, gave rise to differential reserve requirements and discretionary lending through the discount window, which could make allowances for these individual circumstances.

While the diversity in the EU is similar, the regulatory response is markedly different: a new legal framework, a centralized monetary policy, and supervisory mechanisms are being deliberately designed in the context of projected economic and monetary union (EMU) with a common currency. When common currencies were put in place in former times, the monetary institutions were few and simple. One would have thought that the architects of Europe's new system would confront the fact that well-elaborated institutions are in place in every member country, which vary very considerably in a number of important respects. Instead, the new grand design is informed by a powerful set of monetarist and neoclassical assumptions that give little recognition to the institutional structure of European banking and finance.

As seen by the governing bodies of the EU and by the European Monetary Institute, whose job it is to prepare the groundwork for stage three of monetary union, the legal framework defines institutions and provides certain safeguards, such as capital adequacy rules and deposit insurance, which will be uniform in application. The governing idea is that this uniformity will create a "level playing field" for competition, along the same lines as other areas of EU activity (i.e., money is being treated in the same way as peanuts in this respect), and that the competition among financial institutions that will ensue, and the results of that competition, are no business of the authorities.

The EU understands the central purpose of monetary policy to be the containment of inflation. This will be the job of the independent European System of Central Banks (ESCB), whose framework assumes that the member central banks are able to control their money supplies. Furthermore, it is believed that so-called economic policy can be divorced from monetary policy and subject to the principle of subsidiarity, while the ESCB is responsible for monetary policy. No explicit mechanisms for coordination of "economic" policies are proposed, although the need is recognized.

The question of bank supervision gets barely a mention in the Maastricht Treaty. It is seen as separable from the issue of monetary control. And yet there are plans for deposit insurance, and one hopes that the ESCB will, at least in extremis, be prepared to act as lender of last resort. To separate these matters is bizarre and irre- 
sponsible. There is little excuse, after the extensive debates on moral hazard and deposit insurance that have taken place in the economics literature.

The assumptions behind these propositions are recognizable: the neoclassical faith that competition will always throw up the best result; the monetarist beliefs that central banks can control the money supply, that this control is necessary and sufficient to defeat inflation, and that low inflation is necessary for growth; and the Hayekian belief that government intervention is inimical to monetary control. The origin of the idea that monetary and "economic" policies (i.e., fiscal policies) could be kept separate is a legacy, oddly enough, of "bastard" Keynesianism.

Many criticisms can be made of these assumptions and the policies based on them. Most important perhaps is the deflationary bias they impose, but this has been much commented upon. Here we wish instead to address the issue of the suitability of these assumptions to the reality of European financial institutions and some of the likely effects of the future shape of those institutions.

\section{Features of EU Monetary Institutions}

European banking and financial institutions differ greatly in both the degree of their development and their direction. The extent of the use of bank liabilities as money is the hallmark of "stage two," when the banking system can create credit independently of saving [Chick 1986]. According to the statistics for 1991-93 [International Financial Statistics 1995], the ratio of cash to demand deposits (C/DD) in Greece is 83.5 percent. On this crude indicator, Greece may still be a cash economy. Yet Greece has the largest number of bank branches per capita in Europe! The C/DD ratio of the next highest cash user, Ireland, is only 43.1 percent. At the other extreme is the United Kingdom, with a C/DD ratio of 7.5 percent.

The different direction of development is most marked in the contrast between the United Kingdom and Germany not just in the matter of universal versus specialized banking, which everybody knows, but in the unification of retail and commercial business in the United Kingdom and the dual banking system in Germany, in which industry and commerce are served by the universal banks and "the public" by savings and cooperative banks. These latter gather mainly savings, which mark them as "stage one"; a surprisingly large percentage of everyday transactions are done with cash. In other words, one tier of banks is highly evolved and the popular tier far less so. Those countries that manage payments through the Post Office Giro are, on the criterion set for stage two, in an earlier stage of development, even though the system is very sophisticated.

As measured by the proportion of the national market captured by the top five banks, the United Kingdom, Luxembourg, and Germany are low-concentration countries, but this perception is distorted by foreign banks in the first two and 4,000 "popular" banks in the latter. Denmark, Portugal, Greece, and the Netherlands 
show high concentration (in ascending order, with the top five banks in Holland capturing 84 percent of the market) [Price Waterhouse 1988].

European commercial banks are supplemented in each country by a variety of institutions: building societies and other mutual or cooperative banks, rural/agricultural banks, and the like. They vary in the composition of ownership, measured by the percentage of assets: only 6.8 percent of Portuguese bank assets are in private, non-foreign, non-mutual banks compared to 61 percent in Ireland and the Netherlands. Public ownership dominates in Portugal ( 87 percent), Greece ( 84 percent), and Italy (68 percent), and 53 percent of assets are foreign-owned in the United Kingdom [Gardener and Molyneux 1993, 21].

\section{Evaluation}

A legal framework that imposes uniform definitions on European financial institutions is bound to create a Procrustean bed. There are problems both in cross-country comparisons and with the evolving structure of the financial system within a country over time. Britain had to face the question of defining a bank-for the first time in its long history of banking-just at a time when the demarcations between banks, building societies, securities dealers, and insurance companies were becoming blurred. Market segmentation has perhaps broken down less rapidly in other European countries, but the competitive forces that have been unleashed will surely breach some of the existing borders, as happened in the United Kingdom after Competition and Credit Control in 1971.

Further, to impose a legal framework that only establishes a level playing field and leaves the rest to competition is to abdicate any responsibility for shaping the institutional framework of the future Europe. There is some presumption that the present diversity will be homogenized by competition, but the pattern of the homogenized system, and the winners and losers, are hard to forecast [see Chick and Dow 1995 for an attempt]. As Steinherr and Huveneers [1992, 130] put it:

Unfortunately, our knowledge about competing organisational forms is far from what a scientist would call conjecture: there are some partial theoretical arguments and there is some empirical evidence. Taken together they still do not add up to scientific knowledge. In the end, only experience will be able to tell and survival of the fittest will be the ultimate proof.

The European Commission, for one, appears to believe that the fittest are in some sense the best [EC 1990, 12], whereas scientists do not ally "fittest" with "optimum," nor should we.

Almost certainly, any uniform legal framework will favor large, money-marketcenter banks over banks with regional or other specialized constituencies, whose business does not "travel" well. 
A monetary policy based on monetarist assumptions is painfully at odds with present-day monetary institutions almost throughout Europe. As is well known, monetarism has attempted to bring forward to the present day a theoretical system developed in the time of commodity money. During at least some of the era of commodity money, the proposition that government was in charge of the money supply has at least some credibility. ${ }^{1}$ But it is impossible to sustain that simple belief in economies where the great preponderance of money in the EU is created by banks, not government.

In credit money economies, the belief must be that the money supply can be controlled by controlling the money base. But this requires that the base itself is controllable, that the causality run from the base to the money supply, and that the ratio of reserves to deposits and of the public's preferences for cash as a ratio to deposits be stable. These conditions are unlikely to be met in a time of rapid financial innovation, including off-balance-sheet activity, liability management, securitization, and derivatives trading. The Bank of England gave up reserve ratios as an instrument of monetary control in 1981 in recognition of the inapplicability of the reserve ratio to monetary control in the context of contemporary British banking. While the central problem in any one country concerns the stability of the ratios over time, the operation of a uniform policy across Europe must confront the diversity of banking practices across Europe. Actual reserve ratios in 1991 varied across the EU from 3.8 percent (United Kingdom) to 32 percent (Portugal) [International Financial Statistics 1992].

Another way of making the same point is that monetarism never considers the role of bank credit, either in the generation of the money supply or in fostering economic activity by lending for productive purposes. This bias follows from the archaic, commodity-money origins of monetarism and explains the entirely negative and restricted role money has in monetarist thought. The negative evaluation of bank credit is reinforced by the Ricardian perspective of the Bundesbank, which holds that investment not financed by saving-i.e., which is financed by bank creditis ipso facto inflationary. This contrasts with Keynes, who recognized the inflationary consequences of expanding economic activity but regarded it as a necessary by-product of the expansion process, and only "true inflation" was to be avoided. Whatever one's normative evaluation, the preponderance of bank credit in the operation of the monetary systems of Europe is overwhelming. Whether or not the authorities like this fact, the prospect for a monetary policy that ignores it is not good.

The expectation is that the interest rate will form the centerpiece of monetary policy: one interest rate for Europe. I referred above to the position in the United States when the Federal Reserve was founded: regional economies were distinct then because of distance and poor communications. They are as distinct in Europe now, though the reasons are not so clear: regional disparities cannot be explained 
entirely by the newness of the single market or by barriers of language, custom, or currency, for regional differences in activity exist within nation-states. Differential interest rates, which might encourage growth in depressed regions, are not available within individual European nations now, as they were in the United States at the beginning of this century, because of today's rapid communication. Soon, with a common currency and a common monetary policy, differential rates will not even be available to entire European nations that might need their assistance.

The single European interest rate envisaged will be determined only by the needs of the financial centers of the most advanced and internationally connected countries and will be inappropriate to the needs of the slower-growing countries and the depressed regions throughout the EU.

\section{The Impact of Interest Rates}

Regional problems aside, the conception of a monetary policy based on "an" interest rate is bound to have different effects in different European countries. Let us just take the example of Germany and the United Kingdom. A study of household and business debt [Rowlatt 1995] has shown that Britain is far more sensitive than Germany to variations in short-term interest rates. About 85 percent of British mortgages carry variable rates of interest, and about 67 percent of British households are owner-occupiers, whereas Germany has the lowest rate of owner-occupation in Europe; mortgages in Germany represent slightly more than 20 percent of household debt and less than a quarter of these are variable-rate contracts. The character of other household debt is more difficult to assess, but Rowlatt reckons that some 77 percent of all household debt carries variable rates, whereas the figure for Germany is less than 20 percent. Furthermore, the level of household debt in the United Kingdom is the highest in Europe.

Similarly, a higher proportion of loans to companies in the United Kingdom than in Germany carry short-term interest rates- 82 percent versus 20 percent-and liabilities show the same pattern, with 47 percent of company liabilities carrying shortterm rates in the United Kingdom and 15 percent in Germany. The conclusion has to be that the United Kingdom is far more sensitive to variations in short-term interest rates, which will be the subject of monetary policy, than is Germany. Rowlatt remarks that these dramatic differences are diminishing-the behavior in different countries is converging-and admittedly I took the polar cases to make my point-but the conclusion that a single policy will ride roughshod over institutional differences that are not small is inescapable. 


\section{A Final Point}

There is one glaring omission in the above analysis that the EU plans also ignore: even if the diversity of European banking were not a problem, the big European banks are playing a global game. The competitive struggle at the top of the range of European banking is not confined to Europe, nor is European monetary policy able to set an agenda, achieved by whatever policy instrument, in isolation from the relations between the Euro, the dollar, and the yen and the opportunities open to Europe's world-class banks to evade policy actions.

\section{Notes}

1. When there was free minting, the public could determine the money supply. Similarly, the government could not control, though of course they could influence, the inflows and outflows of money through foreign trade.

\section{References}

Chick, V. "The Evolution of the Banking System and the Theory of Saving, Investment and Interest," Economies et societes, Cahiers de l'ISMEA, Serie 'Monnaie et Production', No.3, 1986, 111-26. Reprinted in On Money, Method and Keynes: Selected Essays by Victoria Chick, edited by P. Arestis and S. C. Dow. Macmillan/St Martin's Press, 1992 and in The Money Supply in the Economic Process: A Post Keynesian Perspective, edited by M. Musella and C. Panico. Edward Elgar, forthcoming.

Chick, V., and S. C. Dow. "Wettewerb und die Zukunft des europäischen Banken- and Finazsystems (Competition and the Future of the European Banking and Financial System). In Europäische Geldpolitik zwischen Marktzwängen und neuen institutionellen Regelungen (New Institutions for European Monetary Integration), edited by C. Thomasberger. Marburg: Metropolis-Verlag, 1995. Shorter version in English in Money, Financial Institutions and Macroeconomics, edited by A. Cohen, H. Hagemann and J. N. Smithin. Kluwer, forthcoming.

Commission for the European Communities (EC). "One Market, One Money: An Evaluation of the Potential Benefits and Costs of Forming an Economic and Monetary Union." European Economy 44 (October 1990).

Gardener, E. P. M., and P. Molyneux. Changes in Western European Banking. London: Routledge, 1993.

International Monetary Fund. International Financial Statistics. Washington D.C.: International Monetary Fund, 1995.

Keynes, J. M. The General Theory of Employment, Interest and Money. London: Macmillan, 1936.

Price Waterhouse. "The Cost of Non-Europe in Financial Services." In Research of the Cost of NonEurope, vol. 9. Brussels: EC, 1988.

Rowlatt, A. "UK Sensitivity to Short-Term Interest Rates." HMSO Dd 295419 C10, 8/93, 1993.

Steinherr, A., and C. Huveneers. "Institutional Competition and Innovation: Universal Banking in the Single European Market." In European Banking, edited by A. Mullineux. Oxford: Basil Blackwell, 1992. 